\title{
腎機能恢復の動物実験的研究
}

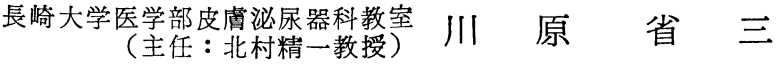

\section{THE EXPERIMENTAL STUDIES OF THE ANIMAL WHICH RECOVERED OF RENAL FUNCTION}

\author{
Shôzô Kawahara \\ Department of Dermato-Urology, Nagasaki University \\ School of Medicine \\ (Director: Prof. Seiichi Kitamura)
}

The removal process of partial renal is the better process than the removal of kidney which leaves only the healthy part, removed the focus. It is congratulatable that by doing this the focus of the residual renal was also made best of and such process increases with the advance of urinery technics and the improvement of chemical therapy. Many persons announced such a condition of recovery of renal function after the removal of kidney but it is very rare to refer of the difference between the case of bi-renal and single, and they regard the case of single renal as dangerous unreasonably. Under the view that there may be the case of organ with the compemsasory function or not from the clinical case and the following case was gained afted testing renal function that by the experimental test of various animals. centering around the renal clearance test.

1) When the executive of the excision process of partial renal, there was quite a lot of number of death from immediately after to the next day, but the imcompleteness of renal function is considered to be the cause of it. Namely one who was cut off about $2 / 3$ of single renal died next day.

This process that renal function is obstacled in comparison with the renal quantity of kidney which was said by Karoner is proved.

2) In case of surgical desease due to higher parasises, the isolation of kidney the digital compression or the rubber hose around the clamp is used in order to minimize the obstacle of renal function caused with it. The time is 5-7 minutes. In this case the digital compression and clamp compression were not recognized.

3) The highest of the renal obstacle are PRF, PBF, GFR. All of them are 1-3 days after operation. The recovery condition is RFF, RBF which are recovered within 2 weeks in single kidney and GFR is recovered a little late. The comparison of bi-kidney and single kidney untill 3 days after the operation the residual renal is bigger in the obstacle then bi-renal but the recovery is I or 2 weeks faster than bi-renal in every test.

4) In the pathological and histological examination until 3 or 4 days after single kidney is much more remarkable in systematic change, namely it is remarkable in hyperemia of the skin, increase of kernel, atrophy of ansa, about 7 days a slight cange can be seem in glomerulus, no. big change and so both of them were not recognized in their change.

5) The above mentioned fact compensated on behalf of another in case of other kidney is healthy namely the removal of part of kidney when the bi-renal, as the recovery of the renal function was compensated with the affiliated kidney at the latest and so there is no anxiety at all, but in case of single kidney it recovers far more speedily than expectation. As it is revealed soon after 3 days that the obstacle of the renal function, it is necessary to be done witn prudent care or preparation. Namely the artificial kidney or peritoneum current was prepared and at a time one should be taken for preparation with the imcompleteness of renal function. Also the excision process is looked to be called the operation which is to be done positively without feeling any fear to the person who has only single kidney. 
（本論交要旨は昭和 31 年 7 月第 44 回及び昭和 32 年 3 月第 45 回及び昭和 33 年 3 月第 46 回日本泌尿器科 学会総会にて発表した)
目次
I ) 緒論
II) 交献的考察
III）腎クリアランスの概念
IV) 動物実験

A）予備実験

(1) 両腎犬に就いて

1）実験方法

口) 実験成績

(2) 単腎犬に就いて

1）実験方法

口) 実験成績

(3) 小括

B ) 本実験

(1) 両腎犬に就いて

1）実験方法

口) 実験成績

(2) 単腎犬に就いて

1）実験方法

実験成績

(3) 両者の比較

C) 病理組織学的所見

(1) 標本の作製法

(2) 各標本の所見

イ）両腎所有の一腎に外科的侵壟を加兄た場合

口）単腎所有に外科的侵襲を加えた場合

八）無侵畩群

）小括

V) 考按

VI) 結語

\section{I）緒 論}

部分的腎切除は病变部丈けを切除し, 健康部走出来る 丈け残すのを目的として施行する手術である.しかしこ の手術に於ては腎莖部血管の銝子による圧迫及び腎実質 にも直接に操作を加える関係上相当に腎機能に障害がか かるとと流分に推測出来る. しかしてその残存部が如 何なる経過を巡つて治瘾し, 吾々の希望通り残存部が機 能を発揮する様になるか否かを知ることは本手微の真價 を判定する上に必要なととである. 事実とのことは高 島”等により証明されて抢るが一概に部分的腎剔除術と
云つても兩腎の場合, 又既沙腎を剔出した單腎の場合 では機能の恢復の経過も同一ではない様である．臨床面 に於ても兩腎所有の片腎の部分切除が單腎の及の部分切 除より腎機能の恢復が著しく嘱延すると云われている.

しかし生態の機能恢復は兩腎の場合乞の一腎の部分切除 を行つた場合ょり單腎の部分切除の際の腎機能恢復が遲 延すると憶測して單腎の部分切除の危險を過大汇強調す るととは決して当を得たものでなく以下著者はこの点を 解明せんとしている。

最近泌尿器科に於いて旺儿亿試及られる單側-兩側-單 腎等の部分切除漈して手術を安全に遂行するためには この腎機能恢復の状況を充分究明する必要がある。

以上の目的の下に著者は動物実驗に上り腎機能の恢復 を腎クリアランス試驗を主として行い，興味ある結果を 得たのでこ〉発表する.

\section{II) 交献的考察}

腎部分切除己は病巢の反を切除し健常腎部分を出来る 丈け残すのを目的として施行する手衔で大越”によれば 人体腎に対し部分切除術を施行したのは1887年Czenry ${ }^{3)}$ が下極に発生した限局性血管肉腫に用いたのが最初で あつてその後腎外傷に Keetley ${ }^{4}$ (1890), 囊腫 と腎瘦 にTuffier ${ }^{5)}$ (1891), 結核飞 Israel ${ }^{6)}$ (1896) Cramer ${ }^{7)}$ (1896) Watsn ${ }^{8)}$ (1896) と19世紀於て既に諸種の疾 患について行われて一時外科医から熱心に迎えられたの であるが，腎の病理及び生理に関する知識が不完全であ り, 診断の不正確, 外科的技術の未熟等により失敗し一 時余り用いられなくなつた. しかしその後泌尿器科的及 びレントゲン学的診断技街が発達し特化本格的に化学療 法が行われるようになつた1949年以後特に増加した。 わ が國では1926年井尻 ${ }^{99}$ にり施行され, 化学潦法発達以 後法楠 ${ }^{10)}$ (1950) が腎結石に施行, 其の 後土屋 ${ }^{11)}$, 市 川, 高安 ${ }^{12)}$, 大越 ${ }^{13)}$, 荒不 ${ }^{14)}$, 城代 ${ }^{15)}$ 等の報告があり, 特に楠, 荒木は單腎部分切除例を報告している. 適䍚に 就ては大越 ${ }^{13)}$ は (i) 病変部が完全に限局されていて表面 に近い程よい（ii）残存部に血液の供給が充分であるよ 3に血管が残し得ること（iii）術後の腎機能が $1 / 2$ 以上残 るとと学述べて抬り單腎の場合は以上の條件を少しゆる めざるを得ないこともあるとのみで具体的に触れていな w.

何れにせよ最近一般外科学及び化学療法の進歩に伴い 
本手衏も脚光を浴びて来たととは事実で，か〉る時に当 り部分的剔除衏施行後の腎機能の推移を知るととは本手 術今後の発展を見る上に重要な事である.

それに関聯して先づ問題になることは片側腎剔出が残 存腎に及法す影響である。これに関しては色々な業績が 発表されている. 中野 ${ }^{16)}$ はその論文中に於いて種々の人 の業績を要約し二大別している. 即ち残存腎臓の肥大と 他憎生であるとし, 更に中野は片腎剔出後姉妹腎を㧓 後 24 時間, 5 日, 12 日の腎蔵の病理組織学的檢查の結 果, 前者に賛意を示している. 而してその恢復の時期, 換言すれば正常に復帰するのは12日以上か つるとしてい る.Enderlen注同様の実驗で 5 日目汇最大の变化を示め し, 徐々に恢復すると述へている. 北村（包）高田も残 存腎による機能の充分な恢復は最少限 1 週間を要すると 云つている.

か>る問題が同一腎内にても外科的侵裂後（この際は 部分切除）に考えられる所である.動物実驗は古くから 多くの人により行われている. Valentin ${ }^{17)}(1839)$, Tillmans $^{18)}$ (1930), Berti ${ }^{19)}$ (1921), Perlmann ${ }^{20)}$ (1926), Herbst $^{21)}$ (1930), Yunck ${ }^{22)}$ (1941) 等発表がある.し かしその頃の実驗は主としてその目的がどの位迄の切除 が生命維持に役立つかという点で色々主張が述べられて いるが大体一致している点は一腎を剔除し残腎の $1 / 2$ は剔 除し得るということ, これらの手街を兩側同時に行えば 腎機能の低下が甚たしく結果が惡く, 間隔を置く可きて それも研究者により区ふだが 2 週間から1ケ月位になつ ている. 邓Bradford (1898), Påssler and Heinecke ${ }^{23)}$ (1905), Janeway ${ }^{24)}$ (1909), Allen, Scharf and Lundin $^{25)}$ (1925), Apfelbach and Jensen ${ }^{26)}$ (1931), Chanutin and Ferris ${ }^{27)}$ (1932) 等は尿濃縮力の減退 により必然的江多尿を来すとし, 反対に Tuffier ${ }^{5)}$ は尿 量つ減少を報告している. 又 Rowntree and Gerag$h^{28)}$ (1921), Young and Davis ${ }^{29)}$ (1917), Cash ${ }^{30)}$

(1924), Scholl (1928) Herbst and Polkey ${ }^{21}$ (1930), Abeshouse and Lerman ${ }^{31)}$ (1950) 等は P.S.P.にて 腎機能を測定し, 術後切除腎の機能が一時減退すること 及び術後 $3 \sim 5$ 週より機能が恢復するととを知つた。し かしこの場合單腎の部分切除汇言及していない。城 代 ${ }^{15)}$ は腎結核の患者 3 名に單腎部分切除を施行, 䘗後の 腎機能の恢復狀況を種々の检査にて明らかにしている. 即与尿量は衙後16 24㭙間で排尿開始し, 約 1 週間にて 衍前の尿量, 比重に共に復している. 血中電解質の変動 に著变はないが血中残余空素は 3 例共術後 1 日著明汇
上昇， $2 \sim 3$ 週にて術前に恢復している. Сの際の残余 窒素では, Tuffier (1908), Bradford (1898), Bainbridge and Beddard ${ }^{32)}$ (1907), Pearce ${ }^{33)}$ (1908), Pilcher $^{34)}$ (1913), Karsner, Bunker and Grabfield ${ }^{35}$ (1915) Judd (1925), Anderson (1926), Chanutin and Ferris ${ }^{27)}$ (1932), Platt ${ }^{36)}$ (1952) 等何れ も血中 に蓄積することを指摘している.

切除量の問題であるが前述の如く Karsner, Bunker and Grabfield ${ }^{35}$ (1915) は犬で全腎実質の 約 $2 / 3$ を切除 すると血中の残余空素が著明に增加することを, 又Judd （1925）は全腎実質の $1 / 3$ だけが残存した臨床例で血中の 残余空素が衍後 9 日間上昇し, 2 ケ月後に始めて正常值 に復帰したと述べ, 域代 ${ }^{15}$ )は臨床例 3 例で切除量の大な る程血中残余窒素が増大し, 尿の排出が荤延したとと党 述べている. 以上により部分的腎剔除獄では切除した腎 実質量汇比例して腎機能は障害される様である。

以上の研究では何れも腎クリアランス試驗により部分 切除後の腎機能を追求して居ないが1955年高島 ${ }^{11}$ の及が

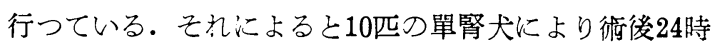
間では RPF, RBF, GFR 共倍高度に低下し, 術後 3 週 間で殆んぞ话前值に戻ると述べその恢復は GFR が前二 者より遲延するとも述べ, 又との腎機障害のため, 單腎 者は術後 3 日間非常に危險な狀態が続くが他腎の健常な 場合认はその代償のため, 危險冲解消されると述べて居 るが, 單腎の部分剔除後と兩腎のそれとの腎機能恢復つ 比較に関する業績の報告は見当らない。

\section{III）肾クリアランスの概念}

此の万法はVan Slyke ${ }^{37)}$ (1928) 等により始めて施 行されたもので一般に Clearance とは或る物質がある 蔵器の機能によつて血液又は血漿から除かれる場合, 單 位時間化何ccの血液又は血漿がその物質に就いて Clear されるかを意味し, その血液または血漿量を $\mathrm{cc} / \mathrm{min}$ 汇 て表わす. その物質が腎蔵の機能汇よつて除かれるとき とれを「腎クリアランス」と云う。

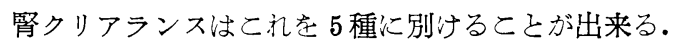
即与i)糸球体で濾過された後, 尿細管で完全に再吸收さ れるもの, ii）糸球体で滤過され心後, 一部分尿細管で 再吸收を受けるもの, iii) 系球体㴔過のみによつて排 泄され，尿細管で再吸收も排泄もされないもの. イヌリ ン, マニトール, フェロシァンカリ, チオ硫酸ソーダ等 がこれに屬する.これが系球体滤過量化等しくなる．iv） 系球体で滤過些られ，更に尿細管からも一部排泄される もの. フェノールスルフォンフタレィン，スギウロン等 
これに屬す。v）腎臟を 1 回血液が循環する間汇糸球体 滤過及び尿細管からの排泄によつて略々完全汇血漿から 除かれるもの，ての「クリアランス」值はあらゆる物質 の中の最高を示めしその值は腎血漿流量化等しくなる. ダイオドラスト, パラアミノ馬尿酸ソータ，ペニシリン がこれに屬する。

\section{IV）動物実験}

\section{A）予備実驗}

(1) 兩腎大に就いて

1) 実驗方法

体重 7.5 11.5 kg程度の雌大を使用, 正常の腎機能を 測定する目的にて腎クリアランス試驗を実施し, 同時化 血中電解質, 血中残余窒素測定の䉆採血を行う.

1) 使用器具

a）尖端附近に 4〜 5 個の穴を開行た多孔ネラトンカ テーテル No. $5 \sim 6$.

b) 持続点滴靜注器具一式, イルリガートル

c）静注用減菌生理的食塩水また浾蒸溜水的 $300 \mathrm{cc}$ 上 膀胱洗條用減菌食塩水的 $200 \mathrm{cc}$

d) PAH $10 \%$ 液 $20 \mathrm{cc}$ とチ才硫酸ソータ10\%液 $100 \mathrm{cc}$

e) $20 \mathrm{cc}$ 採尿用注射器々 $100 \mathrm{cc}$ の採尿用コルベン

f) 10 20ccの採血用乾燥減菌注射器

g) 二重葆酸塩（血液 $1 \mathrm{cc}$ 汶対して $0.1 \mathrm{cc}$ 用いる） を入れた採血用スピッツグラス

ii）实施法

先づ体重を測定し 5ーアリルー5ー（1ーメチルブ チル） - 2-チオバルビッール酸ナトリウム（イソゾー ル） $0.3 \mathrm{~g}$ 蒸溜水 $5 \mathrm{cc}$ に溶かし $2 \sim 5 \mathrm{cc}$ 大伏在静脈 に靜脈麻醉して圖 1 亿見る如く背剀位江特製つ動物手衔 台に固定する. 次江左側の股静脈皮行切開後分離して 元野佂出す。

・開始 5 分前, 盲檢掞よびへマトクリット，血中残余 窒菜, 血中電解質測定のため $25 \mathrm{cc}$ 採血（大股謿脈上り）

・PAH 10\%液15２0ccチ才硫酸ソータ10\%液100cc イルリガートルに入れ温い減菌生理的食塩水または蒸溜 水を混じ全量約 300cc と劣る.とれを阙1亿见る如く予 め露出していた合股静哌より持続点滴腈注を開始寸。点 滴速度は初妨 5 分閆約 $10 \mathrm{cc} / \mathrm{min}$ とし, ついで $3 \mathrm{cc} / \mathrm{min}$ 飞調篗分子る。

・疗道口ょりNo. 5〜6のネラトン氏カテーテルを插 入, その出口等採尿用コルベンの中澊く.

・股靜岅点滴靜注を開始して 20 分すれば藥剂の血中濃 度は略々一定与る。乙の㭙間江膀胱老空虚汇する。 即与

図 $1 \quad \mathrm{~A}$ 股静脈へ点滴静注 $\mathrm{B}$ 股動脈より採血 C ネラトン氏カテーテルで採尿

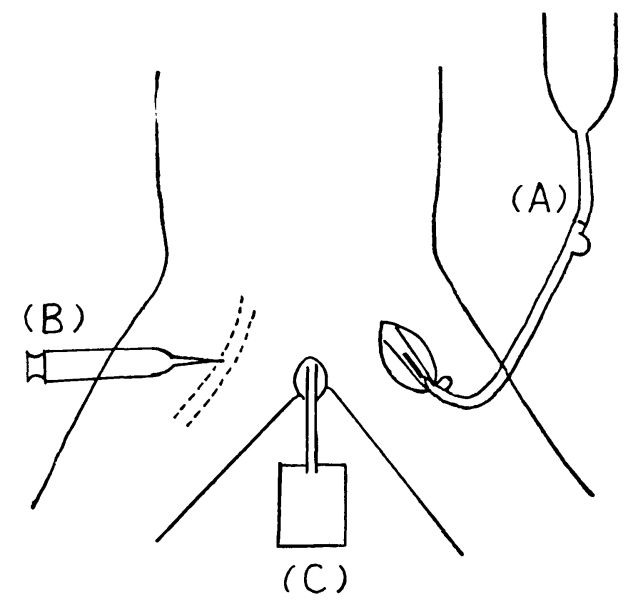

図 2 両腎実験方法

(A)
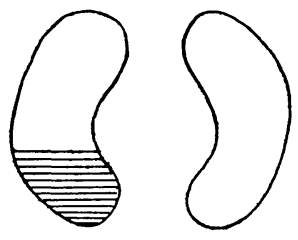

(B)
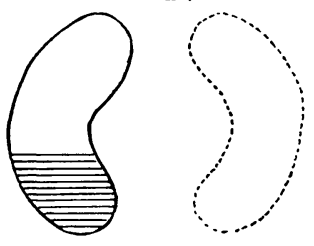

24 時間後

後 腎摘

摘 $\mathrm{E}$ 群, 21 日後 腎绱 $\mathrm{F}$ 群

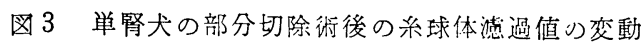
(cc/min) 太い線は平均値

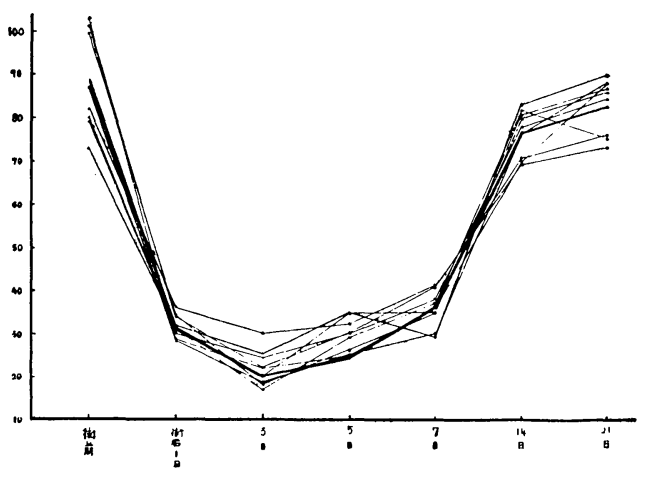


図 4 単腎犬の部分切除術後の腎动漿流量の変動 (cc/min) 太い線は平均值

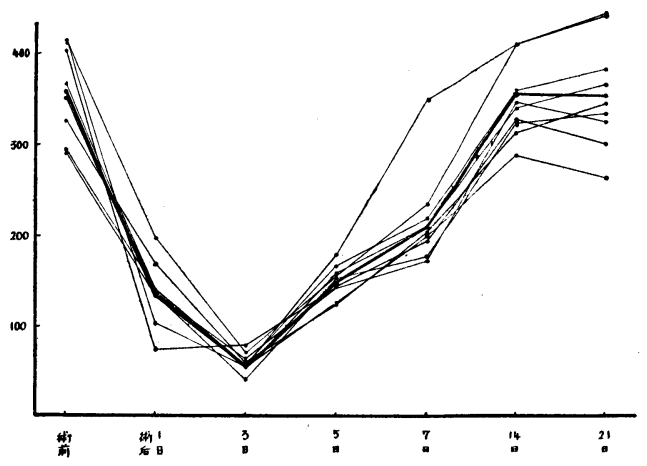

図 5 単腎犬の部分切除術後の堅血流量の变動 (cc/min) 太い線は平均値

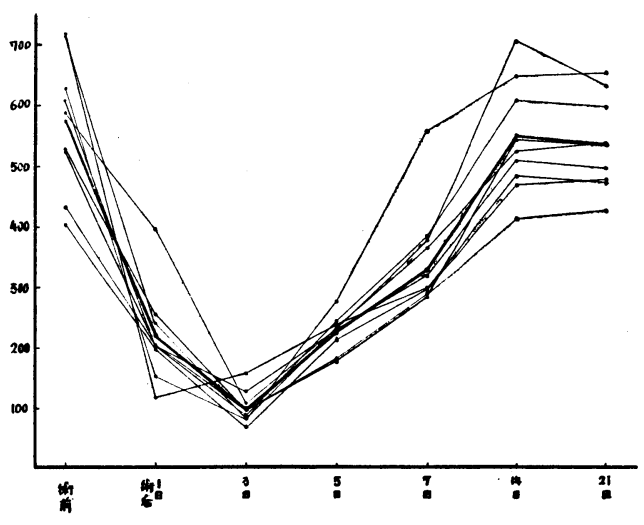

図 6 単腎犬の部分切除術後の血中残余窒素の変動 $(\mathrm{mg} / \mathrm{dl})$ 太い線は平均值

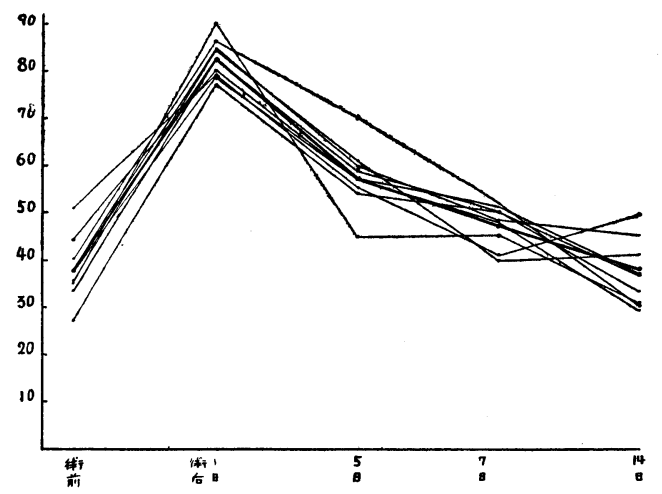

図 7 両腎犬の一腎への部分切除術後の系球体滤過 值の変動 $(\mathrm{cc} / \mathrm{min}) \quad$ 太い線は平均值

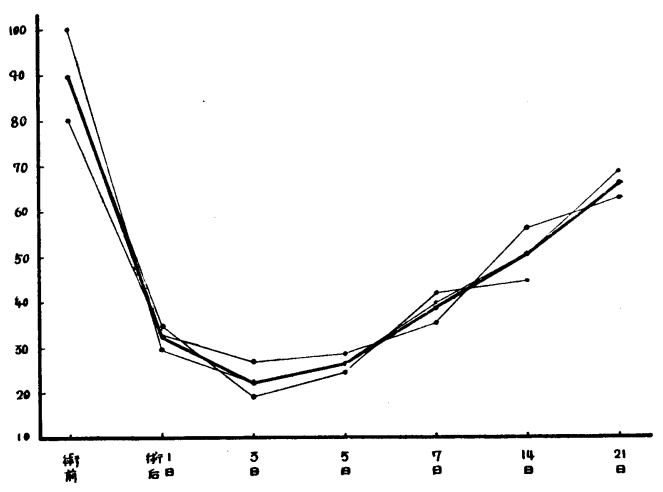

困 8 両腎犬の一腎への部分切除術後の腎血獎流量 の变動 $(\mathrm{cc} / \mathrm{min}) \quad 太 い$ 線は平均值

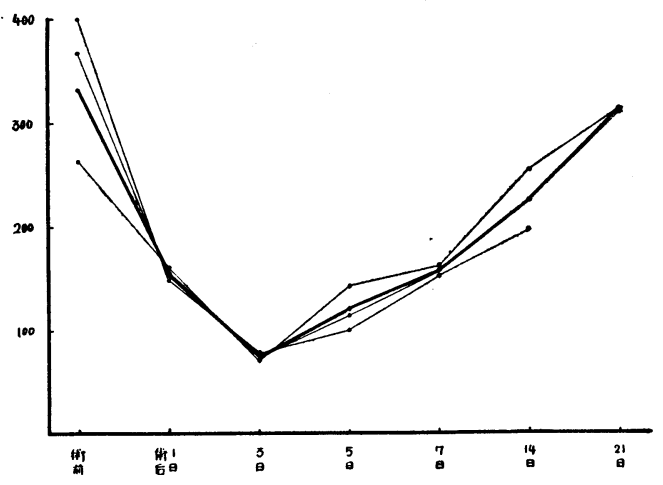

図 9 両腎犬の一腎への部分切除術後の腎血流量の 変動 $(\mathrm{cc} / \mathrm{min}) \quad 太 W$ 線は平均值

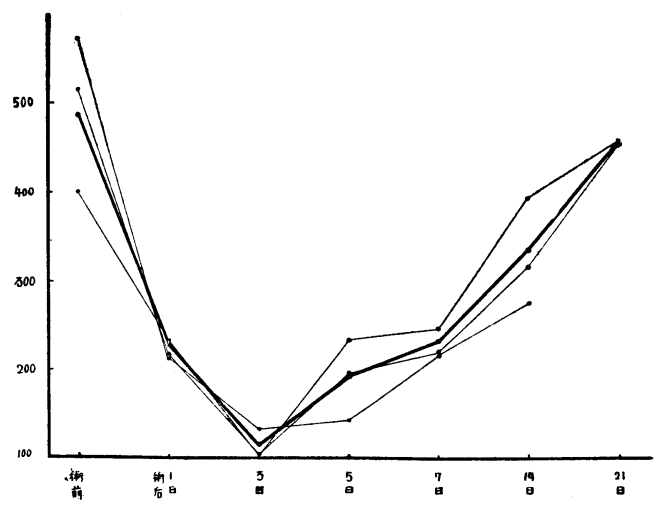


図10 両腎犬の一腎への部分切除後の血中残余窒素 の変動 $(\mathrm{mg} / \mathrm{dl})$ 太い線は平均值

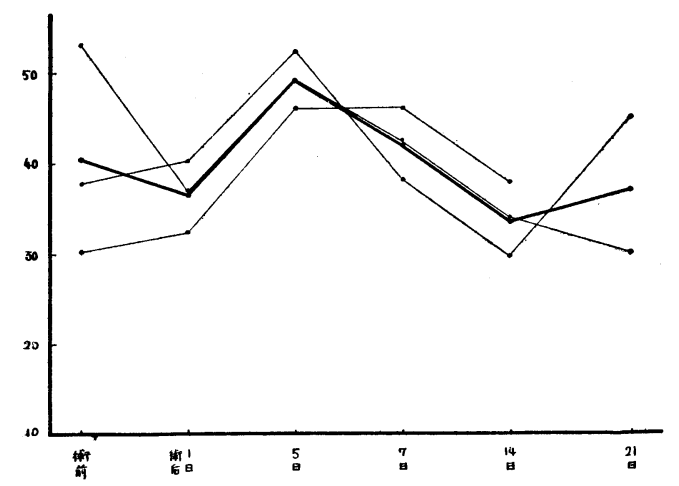

図11 系球体濾過值の術後の変動に於ける両者の比 較 $(\mathrm{cc} / \mathrm{min})$

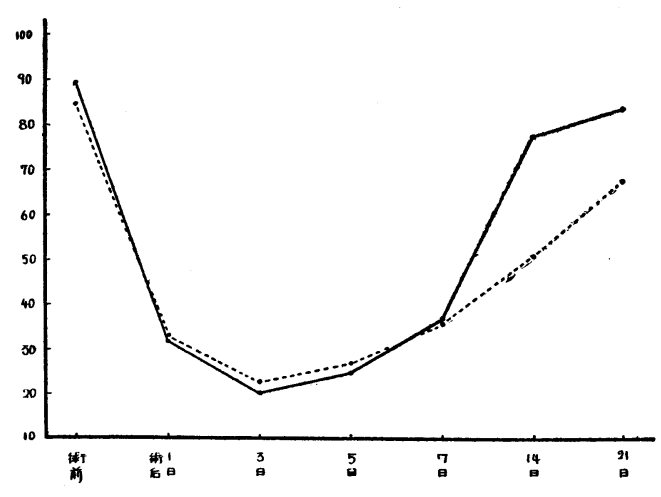

図12腎血墏流量の術後の変動に於ける両者の比較 (cc/min) 一単腎犬 ……両腎犬

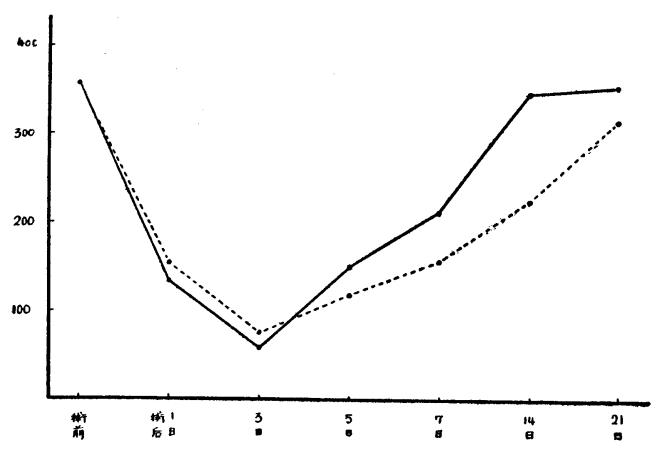

図13腎血流量の術後の変動に於ける，両者の比較 (cc/min) 一単腎犬 ……两腎犬

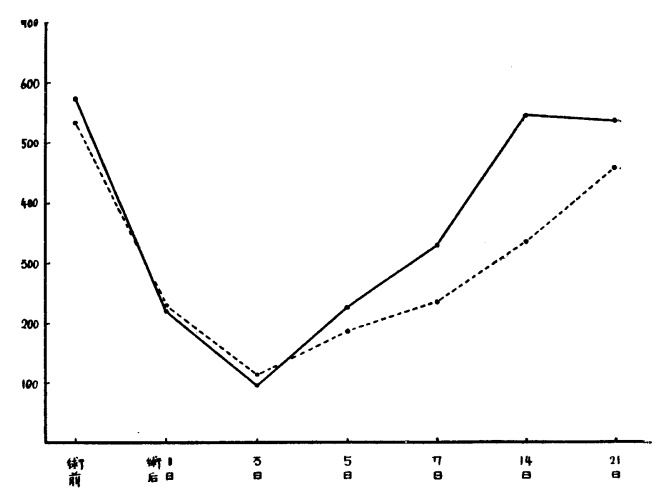

圀14 血中残余窒素の変動に於ける両者の比䡆 (mg/dl) 一一単腎犬 ……両腎犬

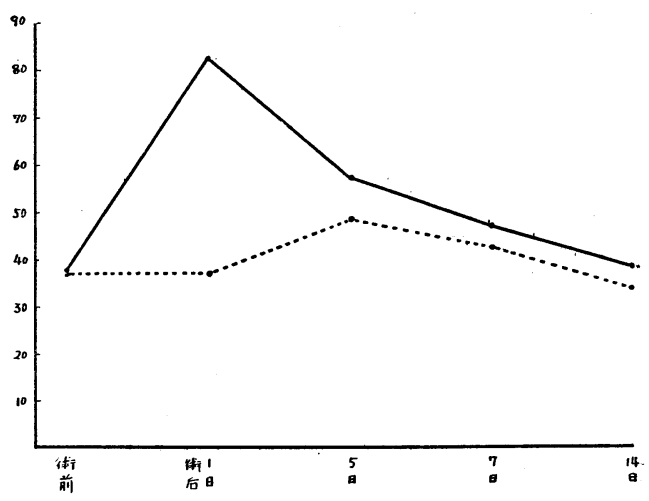

$20 \mathrm{cc}$ の減菌食塩水でカテーテルを通じ 2 回膀胱を洗滌, 最後に $20 \mathrm{cc}$ 空気を送り軽く吸引することに依り膀胱を

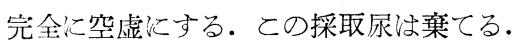

・大島等 ${ }^{38}$ とよれば反対側股静脈より22分, 41 分, 58 分. 採取しているが実驗動物に比較し採血量が多量であると 考える故著者は 30 分並びに50分の 2 回採血にした. 又靜 脈血を用いた結果惊予備実驗としてはともかく正確を期 し難いと J.A. Schannon ${ }^{40)}$, Saul Fischer ${ }^{40)}$, Isadore Pitesky ${ }^{41}$. 加藤, 服部 ${ }^{22}$ 等も述べて居り, 著者はこの 点を考虑してすべて反対側の股動脈より動脈血を採取し た.

・40分 上記と同様の操作により膀胱を洗涤空虚にし 洗淮液圭含めて三角コルベンに採取す.

・60分上記と同様にし膀洗並びに採尿

以上により 2 回のクリアランス測定をした。 
表 1 実験犬の正常値（両腎犬の場合）

\begin{tabular}{|c|c|c|c|c|c|c|c|c|c|c|}
\hline 症例 & 体 重 & $\begin{array}{c}\text { G.F.R. } \\
\text { cc/min }\end{array}$ & $\begin{array}{c}\text { R.P.F. } \\
\text { cc/min }\end{array}$ & $\begin{array}{c}\text { R.B.F. } \\
\text { cc/min }\end{array}$ & F.F. & H.t & $\begin{array}{c}\text { N.P.N. } \\
\mathrm{mg} / \mathrm{dl}\end{array}$ & $\begin{array}{c}\mathrm{K} \\
\mathrm{mg} / \mathrm{dl}\end{array}$ & $\begin{array}{c}\mathrm{Na} \\
\mathrm{mg} / \text { l }\end{array}$ & $\begin{array}{c}\mathrm{Ca} \\
\mathrm{mg} / \mathrm{dl}\end{array}$ \\
\hline 1 & 10.0 & 100.22 & 368 & 533.3 & 0.272 & 31 & 53.12 & 26.1 & 90 & 6.2 \\
\hline 2 & 10.0 & 80.31 & 262 & 400.3 & 0307 & 35 & 37.86 & 18.9 & 94 & 5.0 \\
\hline 3 & 8.5 & 89.34 & 401 & 572.8 & 0.223 & 30 & 30.21 & 22.3 & 86 & 8.2 \\
\hline 4 & 9.3 & 71.50 & 354 & 505.7 & 0.202 & 30 & 50.12 & 21.5 & 125 & 5.4 \\
\hline 5 & 10.2 & 82.04 & 338 & 512.1 & 0.243 & 34 & 29.31 & 17.0 & 101 & 6.0 \\
\hline 6 & 8.5 & 84.31 & 422 & 680.6 & 0.199 & 38 & 21.20 & 20.0 & 98 & 6.0 \\
\hline 平均 & 9.4 & 84.45 & 357 & 534.1 & 0.241 & 32 & 36.98 & 20.9 & 99 & 6.1 \\
\hline
\end{tabular}

表 2 実験犬の正常值（単腎犬の場合）

\begin{tabular}{|c|c|c|c|c|c|c|c|c|c|c|c|}
\hline 症例 & 体重 & $\begin{array}{l}\text { G.F.R. } \\
\mathrm{cc} / \mathrm{min}\end{array}$ & $\begin{array}{l}\text { R.P.F. } \\
\mathrm{cc} / \mathrm{min}\end{array}$ & $\begin{array}{l}\text { R.B.F. } \\
\mathrm{cc} / \mathrm{min}\end{array}$ & F.F. & $\mathrm{Ht}$ & $\begin{array}{l}\text { N.P.N. } \\
\mathrm{mg} / \mathrm{dl}\end{array}$ & $\underset{\mathrm{mg} / \mathrm{dl}}{\mathrm{K}}$ & $\begin{array}{l}\mathrm{Na} \\
\mathrm{mg} / 1\end{array}$ & $\begin{array}{c}\mathrm{Cl} \\
\mathrm{mg} / \ell\end{array}$ & $\begin{array}{c}\mathrm{Ca} \\
\mathrm{mg} / \mathrm{dl}\end{array}$ \\
\hline 1 & 10.0 & 87.21 & 352 & 606.9 & 0.219 & 42 & 33.34 & 19.2 & 98 & 103.5 & 5.2 \\
\hline 2 & 7.5 & 103.15 & 368 & 525.7 & 0.335 & 30 & 40.44 & 21.3 & 136 & 92.4 & 5.8 \\
\hline 3 & 11.5 & 99.06 & 415 & 628.8 & $0: 238$ & 34 & 26.54 & 20.6 & 109 & 103.6 & 7.9 \\
\hline 4 & 9.5 & 73.47 & 403 & 718.5 & 0.182 & $\overline{30 .}$ & 35.81 & 28.1 & 123 & 118.5 & 6.3 \\
\hline 5 & 10.5 & 82.11 & 328 & 529.0 & 0.252 & 38 & 38.05 & 21.5 & 99 & 107.4 & 5.9 \\
\hline 6 & 10.0 & 80.29 & 291 & 404.2 & 0.279 & 28 & 51.03 & 20.0 & 112 & 88.9 & 6.0 \\
\hline 7 & 9.8 & 87.54 & 358 & 716.0 & 0.250 & 50 & 37.53 & 21.7 & 109 & 102.4 & 6.2 \\
\hline 8 & 10.0 & 110.35 & 412 & 588.6 & 0.268 & 30 & 40.21 & 22.4 & 114 & 112.4 & 5.4 \\
\hline 9 & 8.5 & 79.10 & 295 & 433.8 & 0.268 & 32 & 35.17 & 19.9 & 98 & 93.0 & 7.0 \\
\hline 平均 & 9.7 & 89.14 & 358 & $572 ! 4$ & $0: 267$ & 34 & 37.53 & 21.52 & 110 & 102.4 & 6.2 \\
\hline
\end{tabular}

表 3 単腎部分切除に於ける諸種腎機能の諸種腎機能の測定值（GF R）（cc/min）

\begin{tabular}{|c|c|c|c|c|c|c|c|c|c|c|}
\hline \multirow{2}{*}{ 症例 } & \multirow{2}{*}{ 体 重 } & \multirow{2}{*}{ 術 前 } & \multicolumn{3}{|c|}{ 術 } & \multicolumn{3}{|c|}{ 数 } & & \\
\hline & & & 1 & 3 & 5 & 7 & 14 & 21 & & \\
\hline 1 & 10.0 & 87.21 & 30.07 & 21.08 & 30.43 & 38.21 & 78.26 & 82.88 & 指 & 圧 \\
\hline 2 & 7.5 & 103.15 & 28.92 & 22.12 & 25.21 & 36.08 & 70.01 & 88.01 & & \\
\hline 3 & 11.5 & 99.06 & 34.38 & 18.06 & 26.35 & 35.13 & 81.35 & 87.53 & & \\
\hline 4 & 9.5 & 73.47 & 32.35 & 14.55 & 35.12 & 29.34 & 83.54 & 90.17 & & \\
\hline 5 & 10.5 & 82.11 & 36.01 & 30.13 & 32.30 & 42.01 & 69.90 & 73.35 & 鉬 & 子 \\
\hline 6 & 10.0 & 80.29 & 30.99 & 20.02 & 35.09 & 35.89 & 81.11 & 86.27 & 指 & 圧 \\
\hline 7 & 9.8 & 87.54 & 28.37 & 18.33 & 25.39 & 30.22 & 76.53 & 88.21 & & \\
\hline 8 & 10.0 & 110.35 & 34.15 & 22.21 & 30.00 & 41.37 & 71.12 & 76.64 & & \\
\hline 9 & 8.5 & 79.10 & 31.18 & 17.11 & 29.39 & 37.55 & 82.26 & 75.50 & 鉲 & 子 \\
\hline 平均 & 9.7 & 89.14 & 31.82 & 20.40 & 24.69 & 36.20 & 77.12 & 83.17 & & \\
\hline
\end{tabular}

iii）定量法と計算法

・体重より Meeh-Rubner の方式により体表面積孝知 る. $\mathrm{S} \cdot \mathrm{A}^{\mathrm{m} 2}=\frac{11.2^{\mathrm{w} 0.667}}{10.000}(\mathrm{w}=$ 体重 $(\mathrm{g})$

・各洗涤液を含めた尿につき尿量を正確に計り 1 分間尿 量学算出する (V.c.c/min).
・各血液を遠沈し血獎学分離し, 血漿及び尿について速 やかにパラアミノ馬尿酸ソーダ ( $\mathrm{PAH})$ とチ才硫酸ソー ダの濃度を定量する. 定量法は表 9,10 參照.

- PAH Clearance にて腎血漿流量 (RPF) チ才硫酸 ソーダ Clearance にて糸球体濾過值 (GFR) 在得る. 
表 4 単腎部分切除に於ける諸種腎機能の測定值 (R B F ) (cc/min)

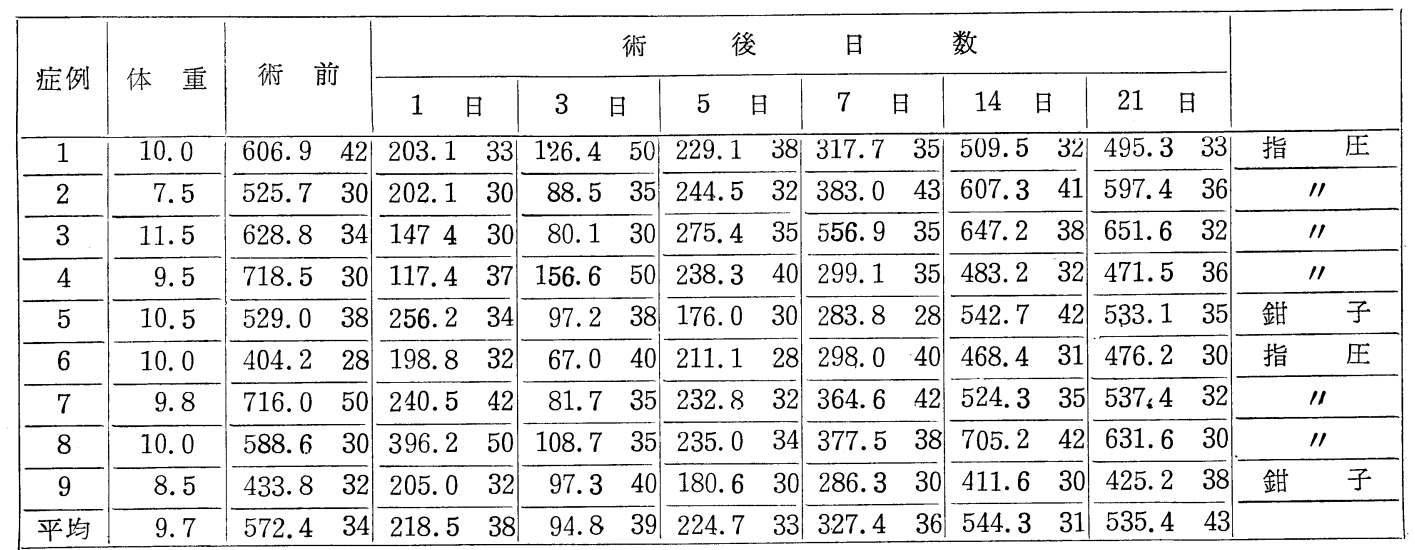

表 5 単腎部分切除に於ける諸種腎機能の測定値 (R P F ) (cc/min)

\begin{tabular}{|c|c|c|c|c|c|c|c|c|c|c|}
\hline \multirow{2}{*}{ 症例 } & \multirow{2}{*}{ 体 重 } & \multirow{2}{*}{ 術 前 } & \multicolumn{3}{|c|}{ 術 } & \multicolumn{3}{|c|}{ 数 } & & \\
\hline & & & 1 & 3 & 5 & 7 & 14 & 21 & & \\
\hline 1 & 10.0 & 352 & 136.0 & 63.2 & 142.0 & 206.5 & 346.4 & 326.9 & 指 & 圧 \\
\hline 2 & 7.5 & 368 & 141.4 & 57.5 & 166.3 & 218.3 & 358.3 & 382.3 & & \\
\hline 3 & 11.5 & 415 & 103.1 & 56.1 & 179.0 & 361.9 & 401.2 & 443.1 & & \\
\hline 4 & 9.5 & 403 & 73.9 & 78.3 & 143.0 & 194.4 & 328.6 & 301.8 & & \\
\hline 5 & 10.5 & 328 & 169.1 & 60.5 & 123.2 & 204.3 & 314.8 & 346.5 & 鉗 & 子 \\
\hline 6 & 10.0 & 291 & 135.1 & 40.2 & 152.0 & 178.8 & 323.2 & 333.3 & 指 & 圧 \\
\hline 7 & 9.8 & 358 & 139.5 & 53.1 & 158.3 & 211.5 & 340.8 & 365.4 & . & \\
\hline 8 & 10.0 & 412 & 198.1 & 70.6 & 155.1 & 234.1 & 409.0 & 442.1 & & \\
\hline 9 & 8.5 & 295 & 139.4 & 58.9 & 126.4 & 200.4 & 288.1 & 263.6 & 鉗 & 子 \\
\hline 平均 & 9.7 & 358 & 135.5 & 57.8 & 148.3 & 210.5 & 345.6 & 353.4 & & \\
\hline
\end{tabular}

\section{濾過率 $(\mathrm{FF})=\frac{\mathrm{GFR}}{\mathrm{RPF}}$}

腎血流量 $(\mathrm{RBF})=\mathrm{RPF} \times \frac{100}{100-\mathrm{Ht}}$

- 血中残余空素は Micro-Kjeldall 法により測定した.

・血中電解質は

$\mathrm{Na}$ は Uranium-Zink-Acetate 法44)

Cl は Silrer-Iodate 法 ${ }^{45)}$

Kは King and Allott 法 ${ }^{46)}$

Ca. Mg は柳沢氏新定量法 ${ }^{47)}$

尚比色は日立製光電比色計を使用した。

\section{口）実驗成績}

以上の方法によつて行つた成績は次の通りである。

i）腎クリアランス 表 1 に示す如くである. 即ち $\mathrm{RBF}$ は $400.3 \sim 680.6 \mathrm{cc} / \mathrm{min}$ で平均值は $534.1 \mathrm{cc} /$ $\mathrm{min}, \mathrm{RPF}$ 沈 $262 \sim 422 \mathrm{cc} / \mathrm{min}$ で平均值は $357 \mathrm{cc} / \mathrm{min}$ GFR は71.50〜 $100.22 \mathrm{cc} / \mathrm{min} て ゙$ 平均値は $84.45 \mathrm{cc} /$ min, FF は0.199 0.307 で平均0.241 であつた.

Houck $^{43)}$ (1948） 站75匹の正常犬について RPF 及び GFR 在体重並びに体表面積との関係について詳細に研 究し, 即与 RPF は 139 43Ccc/min での平均值は $84.4 \mathrm{cc} / \mathrm{min}, \mathrm{FF}$ は $0.225 \sim 0.475$ でその平均值は 0.317 であつた. 高島 ${ }^{1)}$ (1954) は 7 匹の正常犬についてRPF $177 \sim 331 \mathrm{cc} / \mathrm{min}$, 平均值 $226 \mathrm{cc} / \mathrm{min}, \mathrm{GFR}$ な 57 88:8 $\mathrm{cc} / \mathrm{min}$, で平均值 $71.8 \mathrm{cc} / \mathrm{min}, \mathrm{FF}$ は $0.27 \sim 0.38$ その平 均值彷0.32で犬では人間に較べて GFR が高く, $\mathrm{RPF}$ は之に反して低い值を示すため, FF は人間よりも高い 值を示すものである・私の成績も大体これに近い值であ つた. 
表 6 単䁂部分切除に於ける血中残余窒素

\begin{tabular}{|c|c|c|c|c|c|c|}
\hline \multirow[b]{2}{*}{ 症例 } & \multirow[b]{2}{*}{ 体重 } & \multirow[b]{2}{*}{ 術前 } & \multicolumn{2}{|c|}{ 訹 } & \multicolumn{2}{|l|}{ 日 数 } \\
\hline & & & 1 & 5 & 7 & 14 \\
\hline 1 & 10.0 & 33.34 & 82.53 & 58.90 & 47.07 & 43.33 \\
\hline 2 & 7.5 & 40.44 & 80.32 & $\overline{56.75}$ & 48.13 & $\overline{37.05}$ \\
\hline 3 & 11.5 & 26.54 & 76.43 & 54.31 & $\overline{50.19}$ & $\overline{36.33}$ \\
\hline 4 & 9.5 & $\overline{35.81}$ & 84.77 & 61.25 & $\overline{40.05}$ & 40.15 \\
\hline 5 & 10.5 & 38.05 & 85.08 & 60.13 & 48.17 & 45.32 \\
\hline 6 & 10.0 & $\overline{51.03}$ & 79.12 & $\overline{55.58}$ & $\overline{41.18}$ & $\overline{49.91}$ \\
\hline 7 & 9.8 & $\overline{37.53}$ & 78.88 & $\overline{57.02}$ & $\overrightarrow{48.05}$ & 29.65 \\
\hline 8 & 10.0 & $\overline{40.21}$ & 86.11 & 70.38 & 52.31 & $\overline{30.17}$ \\
\hline 9 & 8.5 & $\overline{35.17}$ & 90.13 & $\overline{45.29}$ & $\overline{45.58}$ & $\overline{31.22}$ \\
\hline 平均 & 9.7 & $\overline{37.53}$ & 82.59 & $\overline{57.73}$ & 46.77 & 38.11 \\
\hline
\end{tabular}

A 群（24時間後片腎摘出）

症例 体重 G.F.R R.P.F R.B.F $\mid$ N.P.N $\mathrm{Ht}$

\begin{tabular}{l|l|l|l|l|l|l|}
\hline 1 & 11.5 & 29.76 & 152.08 & 233.97 & 36.98 & 35
\end{tabular}

\begin{tabular}{|c|c|c|c|c|}
\hline 2 & 8.5 & $3 3 . 0 7 \longdiv { 1 6 0 . 1 2 }$ & 235.18 & 40.12 \\
\hline 3 & 8.0 & $\overline{35.17} \overline{149.13}$ & $\overline{213.04}$ & 32.33 \\
\hline 平均 & 9.3 & $3 2 . 6 6 \longdiv { 1 5 3 . }$ & $\overline{227.39}$ & 36.44 \\
\hline
\end{tabular}

B 群 ( 3 日後片腎摘出)

\begin{tabular}{|c|c|c|c|c|}
\hline 1 & 11.2 & 22.32 & $74.31|106.16|$ & 30 \\
\hline 2 & 9.8 & 26.51 & 70.85104 .20 & 32 \\
\hline 3 & 10.5 & 19.21 & $7 8 . 1 7 \longdiv { 1 3 0 . 2 8 }$ & 40 \\
\hline 平均 & 10.5 & 22.66 & $74.44 \mid \overline{113.55}$ & 34 \\
\hline
\end{tabular}

C 群 ( 5 日後片腎摘出)

\begin{tabular}{|c|c|c|c|c|}
\hline 1 & 7.5 & $26.41|114.33| 190.55$ & 49.27 & 40 \\
\hline 2 & 10.8 & $28.28 \overline{141.10} \overline{243.27}$ & 52.30 & 42 \\
\hline 3 & 9.2 & $24.0599 .27 \overline{141.80}$ & $\overline{46.01}$ & 30 \\
\hline 4 & 10.0 & $2 9 . 1 7 \longdiv { 1 0 8 . 0 9 } \overline { 1 6 3 . 7 7 }$ & 50.26 & 34 \\
\hline 平均 & 9.6 & $2 6 . 9 8 \longdiv { 1 1 5 . 9 4 } \overline { 1 8 4 . 8 5 }$ & $\overline{49.46}$ & 36 \\
\hline
\end{tabular}

$\mathrm{D}$ 群 ( 7 日後片腎摘出)

\begin{tabular}{|c|c|c|c|c|c|}
\hline 1 & 6.8 & $39.72 \mid 154.35$ & 237.61 & 42.54 & 35 \\
\hline 2 & 10.5 & $3 5 . 3 0 \longdiv { 1 6 0 . 2 7 }$ & 245.95 & 38.20 & 35 \\
\hline 3 & 9.5 & $4 1 . 9 2 \longdiv { 1 5 1 . 2 9 }$ & 216.13 & 46.12 & 30 \\
\hline 平均 & 8.9 & 38.96155 .30 & 233.23 & 42.28 & 33 \\
\hline \multicolumn{6}{|c|}{$\mathrm{E}$ 群 (14日後片腎摘出) } \\
\hline 1 & 10.0 & $50.83 \mid 225.00$ & 330.88 & 34.01 & 32 \\
\hline 2 & 8.0 & $\overline{56.21} \overline{254.18}$ & 39 & 29.98 & 35 \\
\hline 3 & 9.5 & 44.58192 .39 & 274.84 & 38.00 & 30 \\
\hline 平均 & 9.1 & 50.54223 .85 & 332.26 & 33.66 & 32 \\
\hline \multicolumn{6}{|c|}{$\mathrm{F}$ 群（21日後片腎摘出） } \\
\hline 1 & 8.0 & $68.62 \mid 308.51$ & 4453.69 & 30.20 & 32 \\
\hline 2 & 9.0 & 66.27320 .01 & 457.16 & 45.21 & 30 \\
\hline 均 & 8.5 & 67.99314 .26 & 455.43 & 37.70 & 31 \\
\hline
\end{tabular}

表 9 パラアミノ馬尿酸定量法

$30 \mathrm{cc}$ のコベンに水 $10 \mathrm{cc}+$ 血漿（清） $1 \mathrm{cc}$ を入 れる】

$3 \mathrm{cc}$ の硫酸カドミウム溶液を添加 $\downarrow$

施廻混和

1 分間放置

1. 1 規定苛性ソーダ 1 ccを管をふりつ〉添加 $\downarrow$

密栓して激しく振䔽 $\downarrow$

10 分間放置

3,000 廻転, 5 分間遠心

上澄を滤紙を介して試験管にとる

$10 \mathrm{cc}$ 目盛試験管 2 本用意

1 本 (Sample) には滤液 5 cc他には Blank 用 に水 $5 \mathrm{cc}$ 入れる

各々へ 1.2 規定塩酸 $1 \mathrm{cc}$ を混和

0.1 严硝酸ソーダ $5 \mathrm{cc}$ を混和 ।

少くとも 3 分（但し 5 分以内）放置

$0.5 \%$ Ammonium Sulfamata<smiles>[Tl]</smiles>

少くとす 3 分（但し 5 分以内）放置

$0.5 \mathrm{cc} \mathrm{N}-(1-\mathrm{Naphthyl})$-ethylenediamine Dihydrochloride

直射日光を避けて10分間室温放置 $\downarrow$

各々 $10 \mathrm{cc}$ の目盛まで水を加え混和 $\downarrow$

Blank を 100\%の透過率目盛に合わす ।

被検液の透過率を求む。波長は $540 \mathrm{~m} \mu$ (Filter は Green)

$$
\text { ( }
$$

尿では被検尿中濃度が $1 \sim 6 \mathrm{mg} \%$ になるよう適当 に水でらすめ稀釈倍数を記入し，後は上に同じ

ii）血中電解質

$\mathrm{K}$ は $17.0 \sim 26.1 \mathrm{mg} / \mathrm{dl}$ 平均 $20.9 \mathrm{mg} / \mathrm{dl}, \mathrm{Na}$ は $86 \sim 125$ $\mathrm{meq} / 1$ 平均 $99 \mathrm{meq} / \mathrm{l}, \mathrm{Ca}$ は $5.0 \sim 8.2 \mathrm{mg} / \mathrm{dl}$ 平均 $6.1 \mathrm{mg} / \mathrm{dl}$ であつた・

iii) 血中残余窒素

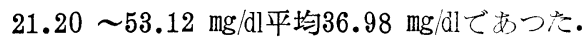

(2) 單腎犬に就いて

1) 実驗力法

（1）の場合亡同様の䧳犬を用意し，体重測定後 5ーア 
表10 チオ硫酸定量注

血漿 $2.0 \mathrm{ml}+\mathrm{H}_{2} \mathrm{O} 14 \mathrm{ml}$ 十タングステン酸ソー ダ液 $2.0 \mathrm{ml}+0.3 \mathrm{~N} \mathrm{H}_{2} \mathrm{SO}_{4} 2.0 \mathrm{ml}$

遠心沈澱

$5 \mathrm{~g} / \mathrm{dl} \mathrm{K} \mathrm{I}$ 液 $1.0 \mathrm{ml}$ +澱粉液 1 滴

$0.1 \mathrm{~N}$ 当

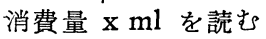

$$
\text { 盲検として }
$$

$\mathrm{H}_{2} \mathrm{O} \quad 12 \mathrm{ml}$ 十タングステン酸ソーダ $1.5 \mathrm{ml}+0.3$ $\mathrm{N} \mathrm{H}_{2} \mathrm{SO}_{4} 1.5 \mathrm{ml}$

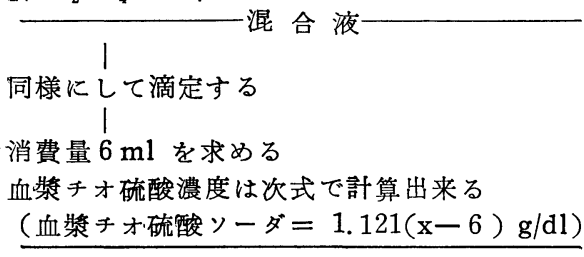

この方法は尿にも応用出来る

リ ルー 5 - ( 1 -メチルブチル $)-2$-チオバルビツー ル酸ナトリウム（イソゾール） $0.3 \mathrm{~g}$ を蒸溜水 $5 \mathrm{cc} に$ 溶かし大伏在靜脈に靜注するととにより麻醉し, 腰部斜 切開法に依り皮切を行い後腹膜に達し, 腎蔵剔出を行い 各層毎に縫合し術後全身狀態がすべて恢復するのを待つ ため最低 1 ケ月放置する. か〉る一群を用意し, その後

(1)で述べたと全く同様の方法で諸檢查学行う.

口）実驗成績

その実驗成績は表 2 亿示す如くである，即ち

i）腎クリアランス

$\mathrm{RPF}$ は $291 \sim 415 \mathrm{cc} / \mathrm{min}$ 平均 $572.4 \mathrm{cc} / \mathrm{min}, \mathrm{RBF}$ 快 $404.2 \sim 718.5 \mathrm{cc} / \mathrm{min}$ 平均 $358 \mathrm{cc} / \mathrm{min}, \mathrm{GFR}$ は 73.47 $\sim 110.35 \mathrm{cc} / \mathrm{min}$ 平均 $89.14 \mathrm{cc} / \mathrm{min}, \mathrm{FF}$ は $0.182 \sim$ 0.335 平均 0.267

ii）血中電解質

Kは19.2〜28.1mg/dl平均21.52 mg/dl, $\mathrm{Na}$ は98〜 136 $\mathrm{meq} / \mathrm{l}$ 平均 $110 \mathrm{meq} / \mathrm{l}, \mathrm{Cl}$ は88.9 $118.5 \mathrm{meq} / \mathrm{l}, \mathrm{Ca}$ 决 $5.2 \sim 7.9 \mathrm{mg} / \mathrm{dl}$ 平均 $6.2 \mathrm{mg} / \mathrm{dl}$ ある。.

(3) 小括

兩腎犬と單骳犬を以上の諸檢查の結果で比較した場合 余り差は無い様である. 即ち, i) GFR 次前者が $84.45 \mathrm{cc} / \mathrm{min}$ 後者は $89.14 \mathrm{cc} / \mathrm{min}$

ii) $\mathrm{RPF}$ 沈前者が $357 \mathrm{cc} / \mathrm{min}$ 後者仗 $358 \mathrm{cc} / \mathrm{min}$

iii） $\mathrm{RBF}$ 沈前者が $534.1 \mathrm{cc} / \mathrm{min}$ 後者仙 $572.4 \mathrm{cc} / \mathrm{min}$

iv） N.P.N. 次前者が $36.98 \mathrm{mg} / \mathrm{dl}$ 後者柱 $37.53 \mathrm{mg} / \mathrm{dl}$

v) 電解質む同様である.

換言すれば一腎剔後も1ケ月を経過すれば一般状態は 全く無侵襲犬と同様になると云える。

B) 本実歌

(1) 兩腎犬僦いて

1) 実驗方法

片腎の場合は問題ないが兩腎所有の場合其の一側腎の 及の機能を知る事は容易でない. 況んや腎クリアランス 試驗沈分離尿採取の必要がある。人体の場合では尿管力 テーテルで採取している. しかしこの場合普通の尿管カ テーテルではカテーテル周邊より漏出するを防ぐために 山藤 ${ }^{51)}$ (特殊カテーテルを使用している．即ち尖端より 3 〜 $5 \mathrm{~cm}$ 下方に膨及を有するもので其れにより尿管口を 塞いで漏出量を殆ご無い様にしたのである。しかし動物 に使用すること梳不能である. 故汇著者は以下の如き工 夫学試みた. 即与圖 2 に示す如く一腎の下1/3在前述しに と同様の方法で腎部分切除を行い, その後24㭙間して片 腎腎剔し, 直後腎クリアランスを行う。とれを A群上 し, 後次々之 3 日後, 5 日後, 14 日後, 21 日後片腎剔出 を B,C,D,E,F 群こす. この際問題となるのは片腎剔出 による姉妹腎への外科的侵裂に対する影響である. 故心 予備実驗として下記のことを行つた。

予犕実驗

イソゾールの靜脈流醉下に側卧位儿固定し, 片方の尿 管を切断, それにNo. 5 ネラトンカテーテル在插入, そ れ学皮咸に固定す．乙れより採尿し尿比重測定並びに流 出狀態字観察与る. その後片腎剔出考行い直後つ流出狀 態, 尿比重は余り変動を認めなかつた.

口）実驗成績

i）この場合実驗方法のあり方で同一犬につき経過立 観察するここは不可能であつた. 即ち表7, 8 に示す如く であつた. 実驗に技術的に困難を伴うので途中での死亡 数が多く從つて例数が少くなつた.

ii）各群に依つて例数が相違するので四 7,8,9,10こ 見る如く21日迄無いのが出来る.

iii) $\mathrm{RPF}$ 及び RBF は表7,8 並びに圖7,8,9で示歺 如く大体 3 週間で術前值近くなつているが, GFR は 3 週間でも未だすつかり恢復していない。

iv）乙の兩腎犬の場合も術後 1 日より術後 3 日に機 
能障害以最高宗した。

v）血中残余窒素は片腎がある䉆余り影響を受けな い様である (圖10).

（2）單腎大に就いて

1）実驗方法

体重 7.5 11.5kgの雌大を予め片腎腎剔を施行少くと も1ケ月を経過せるのを使用した。 とれに部分切除を行 3. この際問題になるのは腎実質の操作中の腎莖血管の 遮断をするのは当然であるが鍸子をかけるか，指圧によ るかである。交献によれば伊藤 ${ }^{48}$ 恃指圧の方が影響が少 ないとしているし教室の濱㟝帛)の業績も同様で，時間は 芥川 ${ }^{50)}$ 等によれば短時間程良好なりと述へている，故に 著者もこれにならい指圧を用い時間も5〜 7分に止め た. 次に部分切除の部位は操作の容易なるととを考慮し て専ら下極面も腎盂腎杯を露出しない樣にした。切除量 であるが約 $1 / 3$ になる様にした. 慎重に施行しても後出血 或は磨醉等により約 $1 / 3$ 法術直後又は翌日迄に死亡する。 以上の操作を加えた 9 匹に就いて予備実驗に述べたと同 様の実驗を術後 24 時間，3 日，5 日，7日，14日及び21 日の 6 四に亘つて実施守る。（註, 麻醉は予備実驗と同

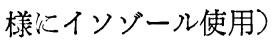

口) 実驗成績

以上の方法によつて実驗を行つた成績は次の通りであ る.

i） 9 匹の術前, 䔎後に於ける各測定值は表 $3,4,5,6$ に見る如くで圖 $3,4,5,6$ で見るとその変動をよく知るこ とが出来る.

即ち, 衍後24時間にて相当の腎機障害が見られるが, 3 日目ではより以上の障害がある様でその後順次恢復し て行く. 一般に RPF, RBF は恢復が早く14日には術前 に戻つているが, GFR は幾分遲く14〜21日迄か〉る様 である.

ii）血中残余窒素, 朩後 3 日にして76.43 90.13 $\mathrm{mg} / \mathrm{dl}$, 平均 $82.59 \mathrm{mg} / \mathrm{dl}$ に上昇し 2 週間にて29.65 49.91 $\mathrm{mg} / \mathrm{dl}$, 平均 $38.11 \mathrm{mg} / \mathrm{dll}$ に恢復してくる.

iii） 2 例に指圧の代りに銝子にゴム管を巻いたもの にて圧鍸したが成績には余り変化を認めなかつた。

(3) 兩者の比較

i) GFR (糸球体濾過值) 圖11參照很後 1 日, 3 日, 5 日に於ては寧ろ單腎大が機能障害大であるが，7日 より14日で單腎犬は急激に恢復しているが後者は稍く劣 る.

ii） RBF (腎血流量), RPF (腎血漿流量) 圖12,
13 參照

前者同様朩後 1,3 日にては單腎大が障害大なるも急激 の恢復で14日で術前に略々戻るが兩腎犬は21日にても稍 々術前に劣る狀態である.

iii）血中残余窒素 圖14參照

前にも述べた如く兩腎大の場合, 片腎が健康であるの で余り影響を受けないのに反し, 單腎大にては術後 1 日 にして急激に上昇 7 日にして略从恢復する.

iv） 血中電解質 前者と同じ理由で比較するに值し ないので少数例に行つたに過ぎない故数值を出すに至ら なかつた。

(4) 小括

以上により下記に迅べる事が明らかとなつた。

i）外科的侵裂後最大の障害は術後 3 日目である.

ii）衍後 $1 \sim 3$ 日は兩腎大より單腎大が障害は大で ある・

iii) 腎血漿流量 (RPF) 腎血流量 (RBF) が 糸球 体滤過值 (GFR) より單腎大, 兩腎大共恢復が速い. 即 与前者は單腎大では 2 週間, 後者は 3 週間である.

iv) RBF, RPF 共單腎大は 7 日目頃より急激に恢復 するが，兩腎犬は徐々に恢復する

v） 剔除腎質量は一腎の約 $1 / 3$ であつた。重量にして $5 \sim 8 \mathrm{~g}$ であつた.

vi）腎莖部血行の遮断は主に指圧, 時にはペアンに コム管を巻いたのを使用した. その時間は $5 \sim 9$ 分平均 7 分であつた。

C) 病理組織学的所見

（1）標本の作製法

実驗動物（雌犬）の腎臟の下部に外科的侵裂（部分切 除)を加光たので組織標本としてはその上半部に於いて 切片を取り直接の外科的侵䰚の影響を避けた。染色法は 普通染色法へマトキシリンェオジン法による.

（2）各標本の所見（附 顯微鏡組織写真熋）

イ）兩腎所有の一腎に外科的侵裂を加えた場合

i）直後 : 被膜に軽度の出血があり, 絿体の一部に は円腔擴張があり, 又液貯溜, 係蹄萎縮を見るものがあ る.

ii） 12時間後 : 所々に糸球体内胿の 液貯溜（部位に よつては一見半月体様を示す) 及び充血が散見されるほ か, 間質の充血も可成り著しい. 即与 i)ii) に於ては急 性循環障害の所見であつた。

iii） 1 日後: 一般に糸球体係踥の大型化, 即与代償 性で刃核増多の傾向が見られる。 
刘照（両腎所有の片腎剔）無侵襲

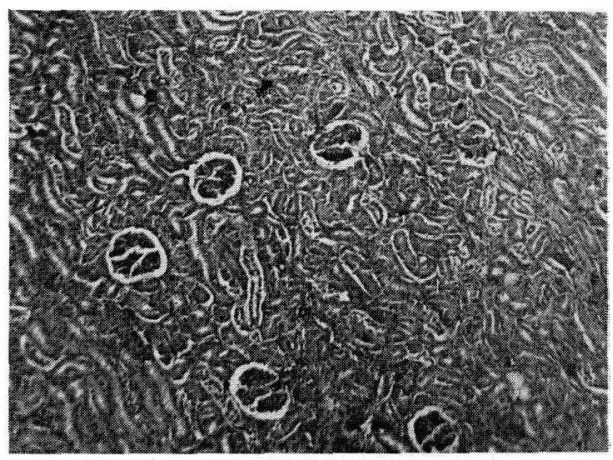

対照

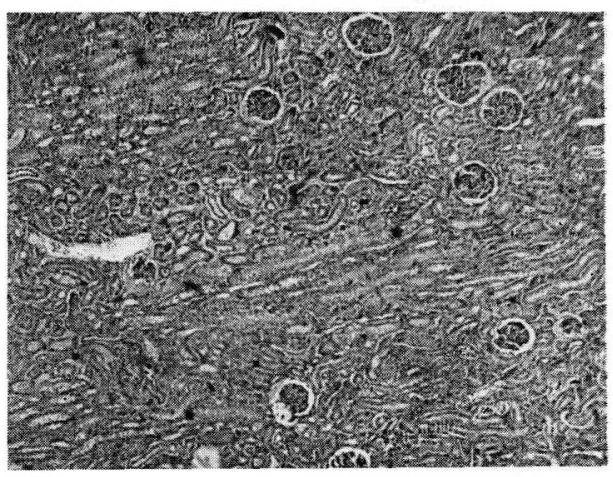

两腎犬（直後）

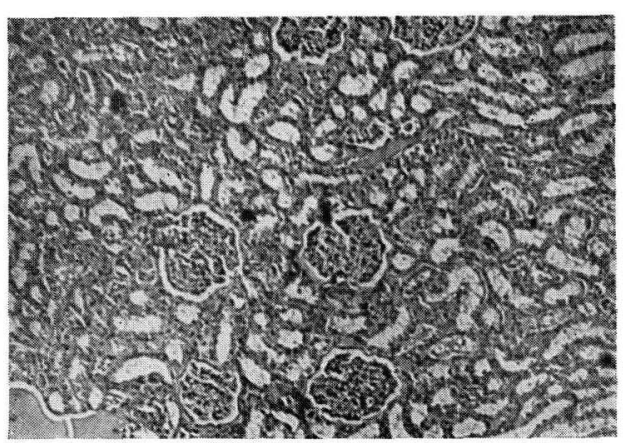

iv） 3 日後 : 被膜に軽度の円形細胞浸潤を見る以 外, 菱縮性係蹄学少数汇認內る.

v） 4 日後 : 極く少数の萎縮性係蹄を見る以外，著 変圭し.

vi） 6 日後: 前者比略ふ同じ

vii） 7 日後: 稍々多数の糸球体に菱縮性変化を認 める.

viii） 39 日後 : 一部に於いて被膜稍々陥凹し小型の
両腎犬 (12時間後)

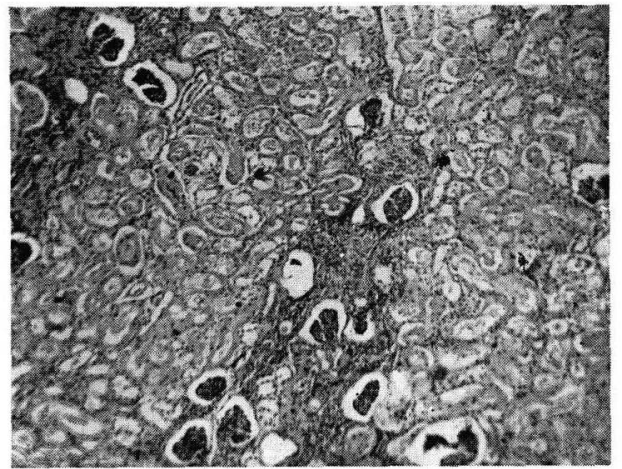

両腎犬（ 1 日後）

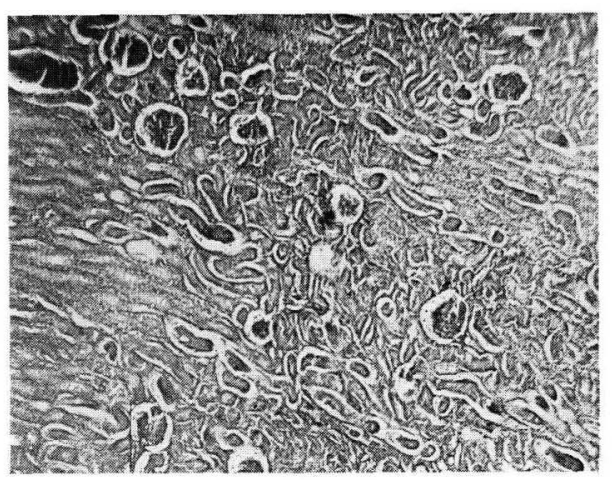

両腎犬（ 3 日後）

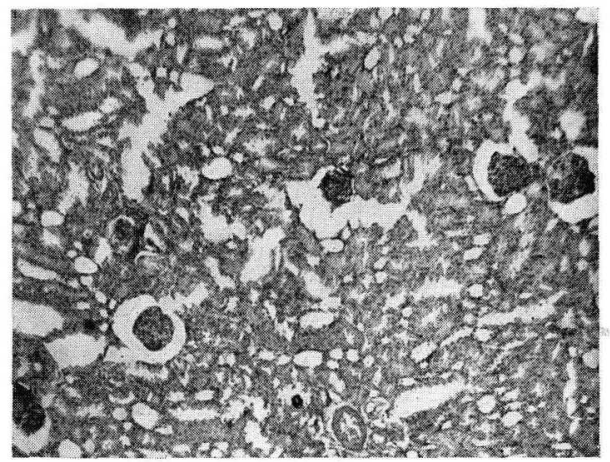

係蹄学もつ小糸球体が多数集合し周围には少数の尿細管 を有する結合織, 円形細胞の浸潤等が見出される。

口）單腎所有江外科的侵襲を加えた場合

i) 1 日後: 被膜任白血球学主上多細胞浸潤, 出 血, 浮腫, 糸球体の大小不同, 係踣萎縮を示すものが可 成り多い.

ii） 3 日後 : 被膜に軽度の細胞浸潤があり, 又係蹄 に軽い核増多がある。 
両腎犬（ 4 日後)

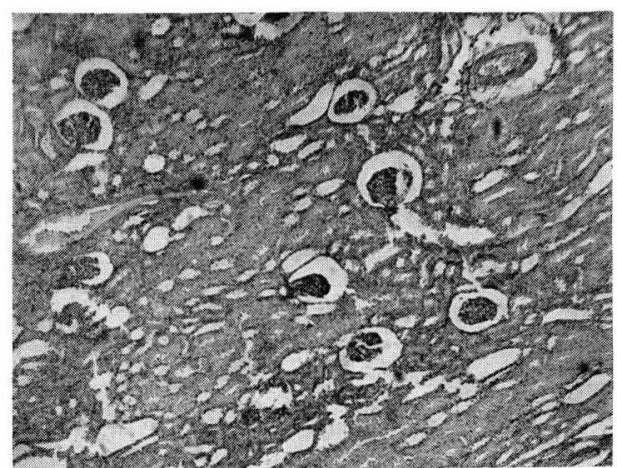

単督犬 ( 1 日後)

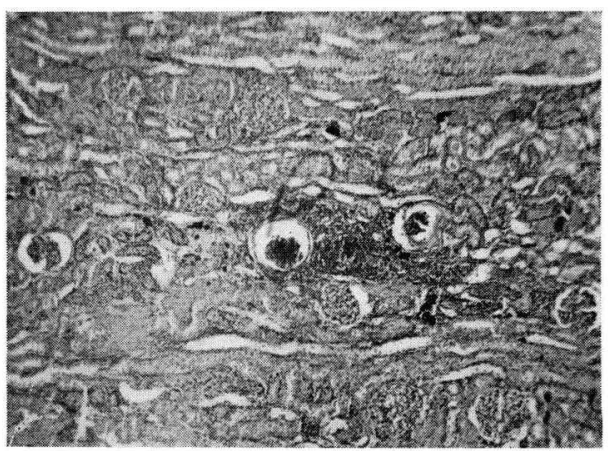

単腎犬 ( 3 日後)

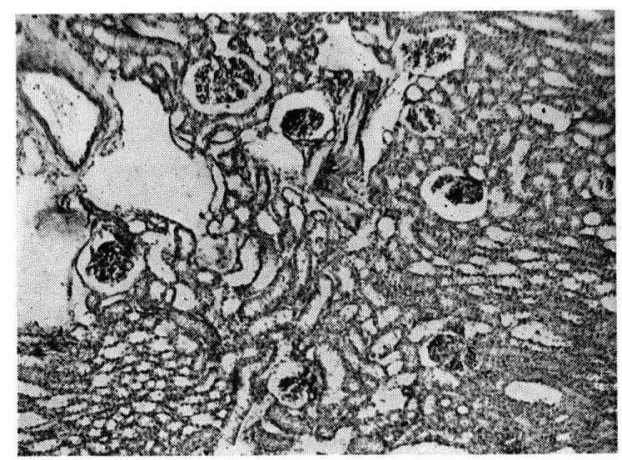

iii） 4 日後: 被膜 ゙゙線維性汇肥厚し, 糸球体は略々 正常大のものが多いが，大型化ないし核増多学見るもの もある. 即方代償性じるる。

iv) 5 日後：前者と大差なし.

v) 18 日後: 著変なし.

vi） 25 日後：糸球体の一部液貯溜老散胃军.

vii） 30 日後: 前者に同じ.

viii） 60 日後：著変を認め難い.
単腎犬 (18日後

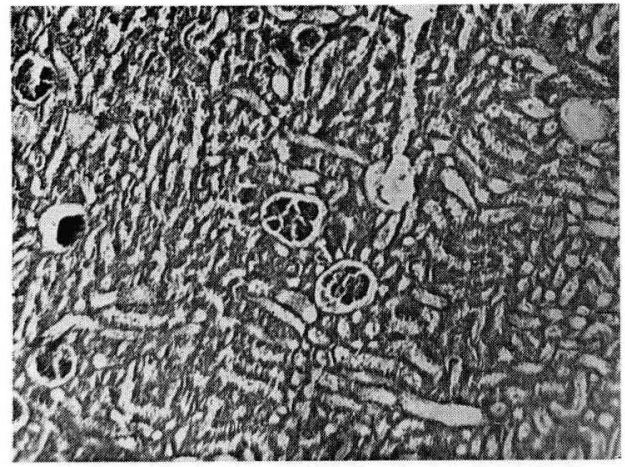

㧛腎犬 ( 4 日後)

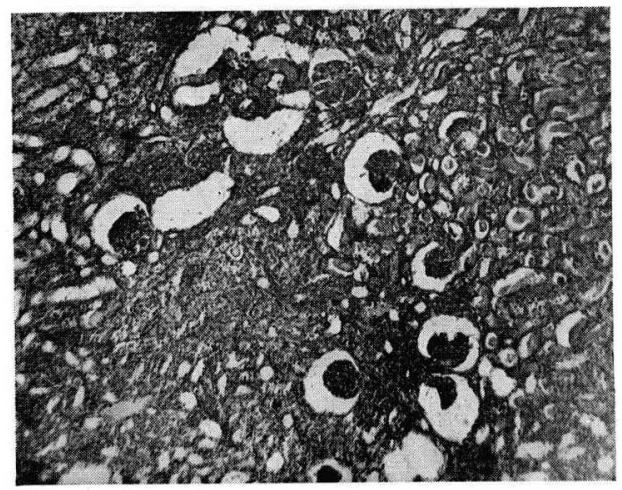

八）無侵竡群 対照として作製した.

i）片腎剔出後 6 日後 : 全般に軽宽に充血性である以 外, 糸球体等に変化なし。

ii）兩腎听有の片腎剔出：全標本に変化なし.

）小括

i）一般こ変化があるのは兩謷, 單腎字併せて腎被 膜, 糸球体で尿細管, 間質には余り変化劣認めない.

ii) 直後より4 日頃迄な單腎の方が組織学的所見は 著明である。

iii）少数の萎縮性係蹄は無侵塑群にも見られ病的上 考へられない様である。

iv）総じて普通染色に関する限り著明な変化沈なく 僅かに代償性に糸球体の大型化が見られる程度である.

(顯微鏡組織写真は総べて $5 \times 10$ 兩腎犬の直後のみ $5 \times 10$ より稍と大なり)

\section{V) 考 按}

既に緒論にて述べた如く腎部分切除は病巣の及を除去 して健康部のみを残寸腎剔術より進んだ手術法である. かくするととにより再発した残存腎の病巢にも善処され 
得るものである.かつる万法が泌沓器科手術発達と化学 療法の進歩に伴い, 再び増加して来たことは慶賀すべき ことである・しかしとの際注意卞可き虻，か〉る腎部分 切除後の腎臓機能の恢復狀態を種从の人により研究発表 されているが, 多くは漠然と部分切除後の腎機恢復とし て述へ，兩腎の場合と單腎の場合との相違汇言及されて いない. 但し高島 ${ }^{1)}$ 梳雨者学別订て言及しているが單腎 の場合を不当に危險視している．著者は兩腎所有の一腎

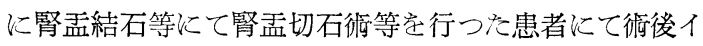
ンジゴカルミンの排泄試驗にて1ケ月以上経過して始め て患側の排泄を見た例を数多く経驗している.また城 代 ${ }^{15)}$ の論交にある様汇腎結核にて片腎剔出した單腎に結 核病巢あり, その部分切除をした場合, 微後16２4時間に て排尿を見て，血中残余窒素々14日にて衡前湫復して いる. 以上の臨床例より代償機能学有守る場合と否とは その恢復狀沉注自ら相違があるのではあるまいかとの見 解の許に既述した実騟学行つた. 勿論腎の機能とは複雜 多岐で色々の因子が関與していることは言を俟たない。 そしてその外科的侵襲の発生機轉も亦恢復の機轉が複雓 であろろととは容易化考えられる。著者はその中, 腎ク リアランス試驗と血中残余窒素並びに病理組轼学的所見 によつてその䐌機能の变化を見たのであるが相当の変化 が見られた。

A）先づ実驗動物であるが個体差の少いとと注家鬼が まさつているが数包の外科的侵襲佂耐える必要があるの で個体差の点で難点が多少あるが大定使用した。 それも 採尿の点で雌性成犬の及使用した。 因及汇先人もすべて 同様である.

B）腎部分切除琎施行に際し直後より翌日に亘つて死 亡したのが相当あるがその原因としては術技失敗もある が腎機不全も考えられる。即ち單腎にて約 $2 / 3$ 切除したの は翌日死亡した。このととは Karoner ${ }^{35)}$ 等が云う腎実 質量化比例して腎機能は障害されると云うことを立証し ている.

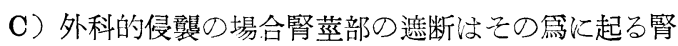
機障害を最少限にする篇, 楠が云う如く指圧或柱鉬子に ゴム管を巻いたのを使用, 時間は 5 〜分とした。この 際指圧と圧鍸の差は本試驗では認められなかつた。

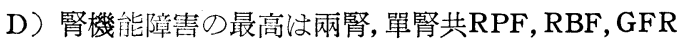

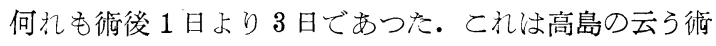
後 1 日とは幾分相違がある. その恢復状況であるが, RPF, RBF は恢復が單腎では 2 週間で GFR 汹稍々造 れる.兩腎, 單腎の比較は獄直後 3 日迄は兩腎は残腎代
償の故か單腎の方が障害が大であるが恢復は諸檢查共單 腎の方が 1 週間から 2 週間速い。

E) 病理組織学的檢查にても術後 3 乃至 4 日迄注單腎 の方が兩腎より組織的变化即ち皮質の充血, 核の增多, 係蹄の萎縮が著明である.7 日頃では僅ふに絿体に萎 縮性変化を見る程度で余り変化なく兩者に差異を認めな くなる，即ち糸球体滤過值の恢復が退いのもうなづける 様である。

F）兩腎の場合臨床的に 1 ケ月近くも侵襲腎の機能恢 復の日数を要する症例に比較して実驗的でも時化ある が，單腎の場合は一般に 2 週間位で恢復することが分つ た.

G）以上の事実は他側腎が健常な場合, 即ち兩腎の際 の部分切除屿その腎の機能恢復が運くても姉妹腎が代償

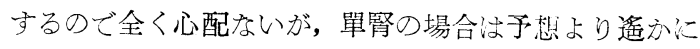
早く恢復するが術直後より 3 日迄沙非常伦危險な腎機能 障害つ狀態に曝される訳であるから細心の注意なり用意 が必要である. 即ち腎機代償となり得る人工腎臟或法腹 膜潅流を準備し一時的謷機不全化備える可きである。し かしてての危險期を過ぎれば全くの一過性の腎機不全で あれば永久的の腎機能の点では少しも心配はない。

\section{VI) 結 語}

臨床面に於て兩腎の一腎に外科的侵襲を加えた場合單 腎汇同一侵翼を加えられた場合に比しその腎機能恢復ぶ 遲延される事は明白であるが著者㳉実驗動牧(雌性成犬) を使用, 予め單腎大と兩腎大を用意し, 腎クリアランス 試驗等により各々の部分的腎剔除後の経過を檢討し, 次 の結論を得た。

A）部分的腎剔除後 3 日にして該腎の RPF, RBF, GFR 何れも高度胝下する. 兩者の比較は單腎犬がよ り低下する，その恢復狀態は RPF RBF，が GFR より 稍々早く RPF, RBF は 2 週間, GFR にても 3 週間ご 術前に戻るが兩腎犬は何れも 1 ～週間遲延する.

B）血中残余窒素は單腎犬では術後 1 日で急増するも 兩腎犬は他側腎の代償の㩊僅かに上昇するの文である。 しかし單腎大も 1 週間にて術前に戻る。

C）この腎機障害の爲單腎犬は術後 3 日汸危險状態が あるが兩腎犬注残腎の代償で異狀ない。

D）切除量が片腎の $1 / 3$ 位なれば充分に腎機能の恢復可 能である。

E）部分的腎切除衎は腎機不全時の萬全の処置即与腎 機代償としての器具 (人工腎, 腹膜潅流裝置) の準備さ えあれば單腎者にても危惧することなく積極的に施行す 
べき手術と断定したい.

稿を終るに臨み御指導と御校閲を賜つた恩師北村教授 並びに荒木助教授に深甚なる謝意を捧げるとともに，併 せて助言を賜つた教室の野北助教授, 第一病理学教室岡 本博士，土山博士に謝意を表する。

尚本実験は交部省科学研究費に負 5 処大である.

\section{文献}

1) 高島彰夫：泌尿器外科にお㚈る腎クリアランス 試験の研究, 日泌尿会誌, 45, 553, 1954 .

2) 大越正秋: 腎部分剔除術, 泌尿器科新書, 南江 堂, 1953.

3) Czenry: Der nächste und Letzte Fall betrifft eine Partielle Nieren-exstrirpation, die erste ähnliche gelungene Operation. Beitr. Z. Klin. Chir., 6, 511, 1890.

4) Keetly: Med. Soc. Lond., 1, 134, 2, 147, 1890.

5) Tuffier, T.: Soc. de Chir., 1892, 1895.

6) Israel: Diagnose und Operation einer überzähligen Pyonephrotischen Niere. Berl. Klin. Wschr., 45, 1081, 1918.

7) Cramer. K.: Beitrag Zur Casuistik der Subphrenischen Abscesse und der Querresection der Niere. Dtsch, $Z$, Chir., 42, $597,1896$.

8) Watson: Boston city Hosp. Rep., 1896.

9）井尻辰之助：結核腎の部分的切除術及其予後, 医事公論，6, 974, 1931.

10）楠隆光：部分的堅剔除術について, 日本医事新 報, $1460,1260,1952$; 診断々治療, 40,110 , $1952 ;$ 新渴医学会雑誌, $66,217,1952$.

11）土屋交雄：流注膿場の経過をとりたる閉塞性腎 結核, 日泌尿会誌, 43, 91, 1952 。

12）市川篤二, 高安久雄: 第65回東京医学会総会演 説, oct, 1952.

13）大越正秋：堅部分剔除術について，日泌尿会誌， 43, 286, 1952 .

14）荒木竜爾，川原省三：臨床放射線， 2, 760, 1957.

15）城代澳一郎：単留部分切除々腹膜灌流，日泌尿 会誌, 48, 807, 1957.

16）中野等：片側腎臓摘出後における残存堅臟変化 の実験的研究, 皮泌誌, 24, 603, 1924.

17) Valentin: Thesis de doct., 1839.

18) Tillmans, H.: Experimentelle und anatomische Untersuchungen über Wunden der Leber und Niere. Ein Beitrag Zur Lehre von der antiseptischen Wundheilung, Virechow's Arch., 78, 437-474, 1879.

19) Berti, G.: Polichinico Sez. Chir., 28, 261, 1921.
20) Perlmann, S.U. Karris Z.: Über Nierenresektion, Gleickzeitig exper. Beitrag Zur Frage de Blutstillung bei Nierenoperationen durch freie Gewebstransplantation.) Z. Urol., 20, 595, 1926.

21) Herbst, R.H. u Polkey. H.J.: Renal resection, experimental study of postoperative function. Surg. Gyn. Obst., 51, 213-216, 1930.

22) Yunck, W.P.u Forsythe, W.E.: Calyceal resection: report of clinical and experimental cases. J, Urol., 46, 396, 1941.

23) Pässler, u. Heinecke: Versuche Zur Pathologie des Morbus Brightii. Verhandl. der deut. Path. Gesellsch., 9, 99-117, 1905.

24) Janeway, T.C.: Note on the blood-pressure changes following reduction of the renal arterial circulation. Proc. Soc. Exper. Biol. and Med., 6, 109, 1909.

25) Allen, F. M., Scharf. R. and Lundin, H.: Clinical and Experimental Renal deficiency. J. A.M.A., 85, 1698, 1925.

26) Apfelbach, C.W. and Jensen, C.R.: Experimental Chronic Renal Insufficiency in Dogs, with Special Reference to arterial Hypertention. J. Clin. Invest., 10, 162, 1931.

27) Chanutin, A, and Ferris, E.B.: Experimental renal insufficieney produced by paritial nephrectomy. Arch. Int. Med., 49, 767,1932 .

28) Rowntree and Geraghty: Quoted by Herbst. u Polkey

29) Young, H.H and Davis, E.G.: Double ureter and Kidney, with calclous pyonephrosis of one half; cure by resection. J. Urol., 1, 17, 1917.

30) Cash, J.R.: Quoted by Herbst and Polkey.

31) Abeshouse, B.S. and Lerman, S.: Collectire py review; partial nephrectomy versus by pelolithotomy and nephrolithotomy in treatment of localized calculous disease of Kidney, with report of partial nephrectomies. Int. Abst. Surg., 91, 209, 1950.

32) Bainbride, F.A. and Beddard, A.P.: Quoted by Chanutin et al.:

33) Pearce, R.M.: The Infuluence of the reductions of Kidney substance upon nitrogenous metabolism. J. Exp. Med., 10, $632-644,1908$.

34) Pilcher, J.D.: On the excertion of nitrogen subsequent to ligation of successive branches of the renal arteries. J. Biol. 
Chem., 14, 389, 1913.

35) Karsner, H.J.: A Note on the immediate effects of reduction of kidney substance. J. Exp. Med., 22, 544-550, 1915.

36) Platt, R.: Structural and functional adaptation in renal failure. Brit. Med. J., 1, 1313, 1952.

37) D.D. Vanslyke, C.P.: Relationsships between urea excretion, renalblood flow renal 'oxygen consumption, and diteresis. The mechanism of urea excretion. Amer. J. phy., 109, 336, 1934.

38）大島研三，金子好宏：Clearance法に上る腎機 能検査の実際，日本臨床，9,575, 1951 .

39）二村領次郎：近世解剖学, 金原商店, 1943.

40) J.A. Schonnon, Saul Fischer: The renal tubular reabsorption of glucose in the normal dog. Am. J. Phy., 122, 765, 1938.

41) H. Pitesky: Approximation of the tubelar maximun for reasorption of glucose using venous blood for plasma glucose levels.
Amer. J. phy., 165, 407, 1951.

42）加藤敏昌, 服部保：Clearance Test の一私 案, 臨床外科, 9, 31, 1952.

43) Houck, C.R.: Statistical analysis of filtration rate and effective renal plasma flow related to weight and surface area in dog. Amer. J. phy., 153, 169, 1948.

44）藤井昇：生化学実験法, (定量篇). 南山堂, 東京 1949.

45）紊藤正行 : 光電比色計による臨床化学検査, 南 山堂, 1951 .

46) 柴田進 : 光電比色を中心とする臨床化学の技術, 金芳堂, 東京, 1952 .

47）柳沢交正：カルシウムの新定量法 第 5 版, 新 潟医学会雑誌，第66章 $12 ， 837,1952$.

48）伊藤本男: 長期無尿症の大静脈内高張葡萄糖液 注入療法に就て, 日泌尿会誌, 46, 561, 1955 .

49）浜崎栄一: 未発表.

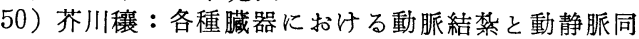
時結禁の場合に関する影響の比較的研究, 日外 誌, 38, 615, 1938 .

51）山藤政史：著者光の私信. 